\title{
Expanding our understanding regarding residents' participation in the workplace
}

Citation for published version (APA):

Olmos-Vega, F. M., Dolmans, D. H. J. M., Teunissen, P. W., \& Stalmeijer, R. E. (2018). Expanding our understanding regarding residents' participation in the workplace. Medical Education, 52(6), 582-584. https://doi.org/10.1111/medu. 13560

Document status and date:

Published: 01/06/2018

DOI:

10.1111/medu. 13560

Document Version:

Publisher's PDF, also known as Version of record

Document license:

Taverne

\section{Please check the document version of this publication:}

- A submitted manuscript is the version of the article upon submission and before peer-review. There can be important differences between the submitted version and the official published version of record.

People interested in the research are advised to contact the author for the final version of the publication, or visit the DOI to the publisher's website.

- The final author version and the galley proof are versions of the publication after peer review.

- The final published version features the final layout of the paper including the volume, issue and page numbers.

Link to publication

\footnotetext{
General rights rights.

- You may freely distribute the URL identifying the publication in the public portal. please follow below link for the End User Agreement:

www.umlib.nl/taverne-license

Take down policy

If you believe that this document breaches copyright please contact us at:

repository@maastrichtuniversity.nl

providing details and we will investigate your claim.
}

Copyright and moral rights for the publications made accessible in the public portal are retained by the authors and/or other copyright owners and it is a condition of accessing publications that users recognise and abide by the legal requirements associated with these

- Users may download and print one copy of any publication from the public portal for the purpose of private study or research.

- You may not further distribute the material or use it for any profit-making activity or commercial gain

If the publication is distributed under the terms of Article $25 \mathrm{fa}$ of the Dutch Copyright Act, indicated by the "Taverne" license above, 
6 Albert M, Hodges B, Regehr G. Research in medical education: balancing service and science. $A d v$ Health Sci Educ Theory Pract 2007;12 (1):103-15.

7 Hodges BD, Kuper A. Theory and practice in the design and conduct of graduate medical education. Acad Med 2012;87 (1):25-33.

8 Tolsgaard MG, Kulasegaram KM, Ringsted C. Practical trials in medical education: linking theory, practice and decision making. Med Educ 2017;51 (1):22-30.

9 Whitehead CR, Hodges BD, Austin Z. Captive on a carousel: discourses of 'new' in medical education 19102010. Adv Health Sci Educ Theory Pract 2013;18 (4):755-68.

10 Tolsgaard MG, Ringsted C, Rosthoj S, Norgaard L, Moller L, Freiesleben NC, Dyre L, Tabor A. The effects of simulation-based transvaginal ultrasound training on quality and efficiency of care: a multicenter single-blind randomized trial. Ann Surg 2017;265 (3):630-7.
11 Gupta DK, Khandker N, Stacy K, Tatsuoka CM, Preston DC. Utility of combining a simulation-based method with a lecture-based method for fundoscopy training in neurology residency. JAMA Neurol 2017;74 (10):1223-7.

12 Regehr G. The experimental tradition. In: Norman G, van der Vleuten CPM, Newble DI, eds. International Handbook of Research in Medical Education. Dordrecht, Kluwer Academic Publishers: Springer International Handbooks of Education 2002;5-44.

13 Norman G. Data dredging, salamislicing, and other successful strategies to ensure rejection: twelve tips on how to not get your paper published. Adv Health Sci Educ Theory Pract 2014;19 (1):1-5.

14 Bordage G. Conceptual frameworks to illuminate and magnify. Med Educ 2009;43 (4):312-9.

15 Dawe SR, Pena GN, Windsor JA, Broeders JA, Cregan PC, Hewett PJ, Maddern GJ. Systematic review of skills transfer after surgical simulation-based training. $\mathrm{Br} J$ Surg 2014;101 (9):1063-76.

16 Dawe SR, Windsor JA, Broeders JA, Cregan PC, Hewett PJ, Maddern GJ. A systematic review of surgical skills transfer after simulation-based training: laparoscopic cholecystectomy and endoscopy. Ann Surg 2014;259 (2):236-48.

17 Norman G. A bridge too far. Adv Health Sci Educ Theory Pract 2016;21 (2):251-6.

18 Brewer M. Research design and issues of validity. In: Reis HT, Judd CM, eds. Handbook of Research Methods in Social and Personality Psychology, 2nd edn. Cambridge, UK: Cambridge University Press 2014;11-26.

19 Curtis JR, Back AL, Ford DW et al. Effect of communication skills training for residents and nurse practitioners on quality of communication with patients with serious illness: a randomized trial. JAMA 2013;310 (21): 2271-81.

\title{
Expanding our understanding regarding residents' participation in the workplace
}

\author{
Francisco M Olmos-Vega, ${ }^{1}$ (D) Diana HJM Dolmans, ${ }^{2}$ Pim W Teunissen ${ }^{2}$ \& Renee E Stalmeijer ${ }^{2}$
}

Learners' active participation in clinical contexts is a crucial aspect of workplace learning. According to Billett, ${ }^{1}$ such participation

\footnotetext{
${ }^{1}$ Department of Anaesthesiology, Pontificia Universidad Javeriana, Hospital Universitario San Ignacio, Bogota, Colombia

${ }^{2}$ Department of Educational Development and Research, Maastricht University, Faculty of Health Medicine and Life Sciences,

Maastricht, the Netherlands

Correspondence: Francisco M Olmos-Vega, Department of Anaesthesiology, Pontificia Universidad Javeriana, Hospital Universitario San Ignacio, Carrera 7\# 4200, 4th Floor, Bogota, Bogotá, Colombia. Tel: 5717946161 (ext 2230);

E-mail: olmos.francisco@gmail.com
}

doi: $10.1111 /$ medu. 13560 arises from learners' engagement with workplace opportunities. Billett used the term 'affordances' to highlight the fact that such situations could be both enabling or restricting in terms of learners' participation. As a result, engagement in workplace affordances is complex and unpredictable. ${ }^{2}$ So much so, that learners that share the same training could end up having completely different learning trajectories, as the experiences they accumulate could vary both in quality and quantity. ${ }^{3}$

Disentangling the factors that influence resident engagement in learning affordances at the workplace is paramount to help maximise the benefits of learners' exposure to clinical environments. We already know from the literature that clinical supervisors regulate to a great extent the types of opportunities that are presented to learners. ${ }^{4}$ Such regulation is influenced by how much they trust their students, ${ }^{5}$ and how competent clinical supervisors gauge their learners to be. ${ }^{6}$ We also know that building a strong relationship between learner and supervisor is crucial for optimising residents' participation in clinical practice. ${ }^{7}$ 
Disentangling the factors that influence resident engagement in learning affordances at the workplace is paramount to help maximise the benefits of learners' exposure to clinical environments

In this issue of Medical Education, Bannister et al. ${ }^{8}$ expand this line of research by exploring the factors that influence how residents engage in opportunities to practise technical skills in a paediatric emergency department. The authors demonstrated that the opportunities to practise technical skills were influenced by factors in three categories: learners', teachers' and environmental factors. Concerning the latter, they described the role of other workplace actors in residents' engagement, highlighting the importance of other team members in accepting and approving residents' participation. For example, the authors described how nurses influenced residents' decisions to attempt a technical procedure, to the extent that they could withhold the opportunity from residents that seem incompetent or unmotivated. Concerning learners' factors influencing opportunities to practise technical skills, the authors described how some residents were uninterested in practising some skills and decided to decline specific opportunities, which seems counterintuitive at first glance because people tend to assume that learners are always eager and willing to learn. We would like to discuss these two issues in depth in the following paragraphs.

First, workplace learning literature seems to be skewed in exploring how learning arises from how students and residents interact with clinical supervisors, ${ }^{9}$ overlooking the importance of other actors, such as nurses or physical therapists, who also have a role in students' learning. Workplace learning goes beyond practising authentic tasks; it involves engaging in a community with a myriad of different actors who hold particular practices and repertoires, which are the primary source of creating or withholding affordances for the learner. ${ }^{10}$ By foregrounding the role of other actors in how residents attempt clinical skills at the workplace, Bannister et al. contribute to an interesting, yet under explored, chapter in the workplace learning literature. Looking at the broader picture will enable understanding and optimising learning in real clinical contexts. Expanding this research agenda includes exploring how residents interact with other so-called non-physician actors, how such relationships influence their learning and what is learned from them.

Workplace learning literature seems to be skewed in exploring how learning arises from how students and residents interact with clinical supervisors

Second, Bannister et al. uncovered a crucial aspect of residents' agency in workplace learning. Not all learners are eager to latch onto all learning opportunities that are presented to them. Workplacelearning literature seems to assume that all learners are interested in an inbound trajectory towards full participation when entering a learning community, overlooking other types of participation that include remaining in the periphery of the community. ${ }^{11}$ Some residents that rotate in settings within their discipline have already decided what type of future practice they want to pursue, and make choices accordingly. As Bannister et al. described it, some residents were not interested in attempting clinical skills that are of interest to an emergency paediatrician, simply because they do not see practising in the emergency department in their future. Further, there are residents that are interested in learning just partial elements of a community of practice body of knowledge. In fact, postgraduate curricula include clinical rotations in settings outside residents' primary discipline; for example, anaesthesiology residents rotate in some internal medicine settings to strengthen their knowledge and skills in perioperative assessment and management of complex patients. Going into a foreign context does not mean that a resident is interested in learning all aspects of those communities, just the elements that seem appropriate for their learning trajectory. How residents decide what to learn and what not, exploring if the resident could make that choice and how practice should be shaped to match such expectations are questions that need further research, especially in residents rotating in foreign settings.

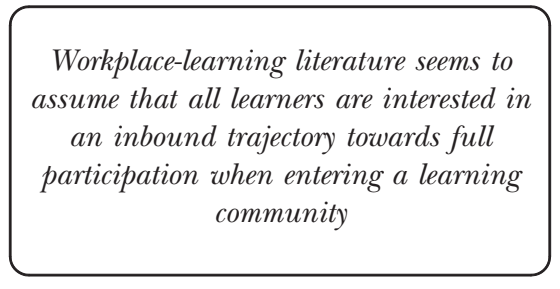

In summary, residents' engagement in workplace learning opportunities is a complex process, as demonstrated by Bannister et al., a process that still needs to be further elucidated. Regarding the environment, the literature is skewed towards the supervisorlearner relationship, missing the role of other actors. Concerning 
the learner, it always seems to assume they will engage in all types of opportunities, overlooking their agency. Mending such gaps includes determining the role of all the members of the community of clinical practice and moving beyond the traditional studentsupervisor dyad focus. It also entails understanding the role of the type of resident participation (peripheral versus central) within a community and how that role shapes his or her engagement with that community. Bannister et al. have now started this important discussion, broaching exciting new avenues that will help us expand our understanding of workplace learning.

\section{REFERENCES}

1 Billett S. Workplace pedagogic practices: co-participation and learning. Br J Educ Stud 2002;50 (4):457-81.

2 Olmos-Vega FM, Dolmans DHJM, Vargas-Castro N, Stalmeijer RE. Dealing with the tension: how residents seek autonomy and participation in the workplace. Med Educ 2017;51 (7):699-707.

3 Teunissen PW. Experience, trajectories, and reifications: an emerging framework of practicebased learning in healthcare workplaces. Adv Health Sci Educ 2014;20 (4):843-56.

4 van der Zwet J, Zwietering PJ, Teunissen PW, van der Vleuten CP, Scherpbier AJ. Workplace learning from a socio-cultural perspective: creating developmental space during the general practice clerkship. $A d v$ Health Sci Educ 2011;16 (3):359-73.

5 Hauer KE, Ten Cate O, Boscardin C, Irby DM, Iobst W, O'Sullivan PS. Understanding trust as an essential element of trainee supervision and learning in the workplace. Adv Health Sci Educ 2014;19 (3):435-56.

6 Kennedy TJ, Lingard LA. Questioning competence: a discourse analysis of attending physicians' use of questions to asses trainee competence. Acad Med 2007;82 (10 Suppl):S12-5.

7 Brown J, Nestel D, Clement T, Goldszmidt M. The supervisory encounter and the senior GP trainee: managing for, through and with. Med Educ 2017;52 (2):192-205.

8 Bannister SL, Dolson MS, Lingard L, Keegan DA. Not just trust: factors influencing learners' attempts to perform technical skills on real patients. Med Educ 2018;52 (6):605-19.

9 Stalmeijer RE. Teaching in the clinical workplace: looking beyond the power of 'the one'. Perspect Med Educ 2015;4 (3):103-4.

10 Wenger E. Communities of Practice: Learning, Meaning and Identity. New York, NY: Cambridge University Press 1998.

11 Fenton-O'Creevy M, Brigham L, Jones S, Smith A. Students at the academic workplace boundary: tourist and sojourners in practice-based education. In: Wenger-Trayner E, FentonO’Creevy M, Hutchinson S, Kubiak C, Wenger-Trayner B, eds. Learning in Landscapes of Practice: Boundaries, Identity, and Knowledgeability in Practice-based Learning. New York, NY: Routledge 2014;43-63.

\title{
Grappling with troublesome knowledge
}

\author{
Luke Y C Chen (D) \& Gary Poole
}

"As the cool stream gushed over one hand she spelled into the other the word water, first slowly, then rapidly... Suddenly I felt a misty consciousness as of

Division of Haematology, Department of Medicine, University of British Columbia, Vancouver, British Columbia, Canada

Correspondence: Luke Y C Chen, Division of Haematology, Department of Medicine, University of British Columbia, 2775 Laurel Street, 10th Floor, Vancouver, British Columbia V5Z 1M9, Canada.

Tel: 001604875 4863;

E-mail: lchen2@bccancer.bc.ca

doi: $10.1111 /$ medu.13587 something forgotten - a thrill of returning thought; and somehow the mystery of language was revealed to me. I knew then that "w-a-t-e-r" meant the wonderful cool something that was flowing over my hand. ${ }^{1}$ "

In this well-known 'aha moment', 7-year-old Helen Keller, blind and deaf, connects the sensation of liquid flowing over her skin with the spelling of the word w-a-t-e-r on her other hand. ${ }^{1}$ Her teacher, Anne Sullivan, had spent months finger-spelling with her, but although Helen had quickly learned to mimic the tracing of words like d-o-l-l, she did not understand the meaning of those letters or their link with the toy in her grasp. The cognitive breakthrough of linking words to the objects and ideas they represent transformed her life; she was able to integrate her sensory experiences with new ways of comprehending and interacting with the world around her.

Although 'aha moments' in health professions education are 